\title{
敷島公園の総合的価値が周辺の生活質に与える影響に関する考察
}

\section{A Study on Structure of influence by Quality of life captured from Total value of Shikishima Park}

\author{
塚田 伸也* 片桐 麻衣** 森田 哲夫*** 湯沢 昭*** \\ Shinya TSUKADA Mai KATAGIRI Tetsuo MORITA Akira YUZAWA
}

\begin{abstract}
An This study examined the effect on quality of life is a large-scale park in Maebashi City. We chose Shikishima Park of Maebashi City as a research subject. A questionnaire survey was conducted for residents, and characteristics of individual and residential areas were estimated and analyzed. By the results of the questionnaire survey, Shikishima Park was evaluated highly for mental utility of green than for active activity such as light exercise. Neighborhood residents of Shikishima Park were highly appreciated for the surrounding environment such as space formation and hygiene conditions. As a result of the factor analysis and covariance structure analysis, we thought that it was possible to show the relationship that the use environment of Shikishima Park affects QOL of neighboring residents as a quantitative structure. It is found that the static use has a strong influence on the usage environment rather than active use. In addition, it was shown that the influence of the environment on QOL is the same value as the influence on the activity of Shikishima Park.
\end{abstract}

Keywords: Shikishima Park, Quality of life, value of park, evaluation structure キーワード：敷島公園, 生活質, 公園の価值, 評価構造

\section{1. はじめに}

\section{(1) 背景}

わが国では，人口減少や少子高齢化への対応が喫緊の課題であ り， CCRC 構想（高齢者が地方に移り住み，健康でアクティブな 生活を送ることができる地域づくり）1)や立地適正化計画（医療・ 福祉・商業等の都市機能がまとまって立地するコンパクト・プラ ス・ネットワークのまちづくり）吕に取り組む都市もある。都市 の形成に際し都市公園は，良好な景観や環境，にぎわいの創出な ど，潤いのある豊かな住環境を形成する上で久かせない都市施設 である。この緑空間を，民間の知恵を活かしながら保全・活用し ていくため，都市公園法の一部改正が 2017 年 6 月に行われた。 改正には，都市公園の再生・活性化を推進するため，園内に保 育所等の社会福祉施設の占用を認めることや，民間事業者による 公共還元型の収益施設の設置管理制度の創設が盛り込まれた3)。 政策評価のベンチマークとして生活質（以下，QOL と称す） を数值化する手法が用いられており，政策評価だけでなく医療な ど様々な概念で QOL に基づく評価が活用されている4)。中でも 都市計画分野における概念から QOL を捉えると， CCRC 構想が 目指寸高齢者が生きがいを持ち健康を維持する環境の提供，立地 適正化計画が目指寸高齢者が安全に暮らせる都市機能の確保や民 間施設を誘導する環境を創出するために，都市公園が整備された ことによる価值が周辺の QOL に与える影響を把握寸ることも重 要と考える5)。これにより, 都市機能の再編の機に, 都市公園を 社会的な課題の解决への 1 つのツールとして活用すること，ある いは民間事業者による公共還元型の収益施設として活用していく ことが考えられる。本研究は，計画条件の 1 つとして都市公園の 価值が QOLに及ぼす影響に着目して検討した。

\section{(2) 既往研究}

都市公園の評価に関する研究は，都市計画や造園学を中心に数 多く蓄積している。中でも近年では, 都市公園と都市公園を取り 巻く周辺環境を包括して評価した研究，社会的課題を背景に高齢
者の生活環境や幼児の保育環境と都市公園の利用実態に関する研 究などが行われている。例えば，田中らは取り巻く市街地の状況 に着目して, 都市公園における利用行動を分析した。結果, 都市 公園と周辺に存在する社寺や川などの「お気に入り場所」の存在 により, 利用行動に変化が見られることから, 回遊性を促すため の計画条件を明らかにすることを課題としている 6)。この計画条 件に対応した研究として, 蔡らは堺市を事例に都市公園の立地と 選択性から捉えたアクセスビリティに着目して調査を行った。結 果，多様なニーズに応えることのできる大規模公園が地域毎によ る利用選択に差異を生じさせている実態を明らかにしている7)。

高齢者の生活環境と都市公園の利用に関する研究としては, 上 原らが高齢者の親水公園の利用に関寸る調査を行っている。結果, 高齢者の利用目的が「散歩」や「ウォーキング」が多いこと, 利 用のきっかけが「公園が出来たこと」「仕事をやめたこと」「健康 を意識して」を理由に挙げ, 課題として「車が通らない」など移 動経路の連続性が重要であると示唆している 8)。幼児の保育環境 と都市公園の利用に関する研究としては, 田中らが駅周辺の外遊 び空間がそしいため近隣の都市公園が園外活動の場として積極的 に活用されている実態 9)，椎野が保育施設の利用から狭小公園の 再評価を行った結果によって計画課題を考察している ${ }^{10)}$

本研究では, CCRC 構想や立地啇正化計画に取り組む地方都市 が増加している現状を踏まえ, 「都市公園の価值が周辺住民の QOL に如何に影響しているかを明らかにし, 都市公園の価值と QOL の関係を構造的に把握する」ことを独自性とした。対象は, 前橋市の敷島公園とした。都市公園の環境を評価する研究として, 小林の文化的生態系サービスに関する評価に関する研究11)などが ある。緑とオープンスペースである都市公園には，公園を利用す ることにより住民にもたらされる利用効果と公園が存在すること による環境など都市構造にもたらされる存在効果の 2 つがある ${ }^{12)}$

本研究では, 利用効果と存在効果を合わせた都市公園の多様な 効果を「総合的価值」として定義し, 前に掲げた近年の先行研究

*前橋市都市計画部

*福島県土木部

**ok前橋工科大学 


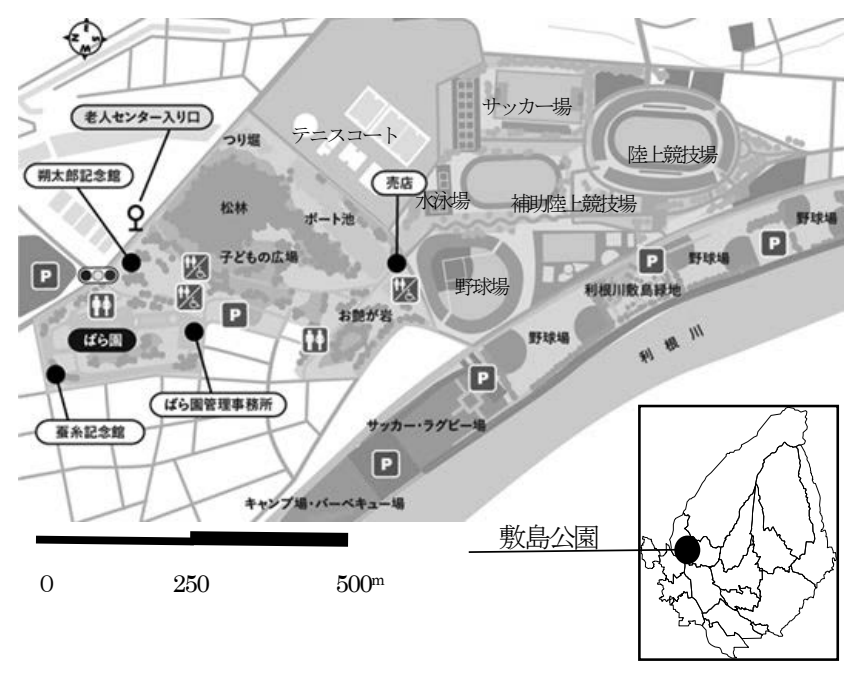

図-1 敷島公園の施設概要 ${ }^{13}$

表-1 アンケート調査概要

\begin{tabular}{|c|c|}
\hline 調 査 日 & $\begin{array}{l}\text { 配布：2016年8月 } 18 \text { 日 } \\
\text { 回収：2016年8月 } 31 \text { 日 (郵送投函期限) }\end{array}$ \\
\hline $\begin{array}{l}\text { 対象地域 } \\
\text { (配布数) }\end{array}$ & \begin{tabular}{|lll} 
敷島町(200) & 荒牧町(500) & 上小出町(400) \\
岩神町(300) & 川原町(200) & 緑ヶ丘町(200) \\
\end{tabular} \\
\hline 調査方法 & $\begin{array}{l}\text { 配布：調査員による戸別配布 } \\
\text { 回収：郵送回収 }\end{array}$ \\
\hline 調査内容 & $\begin{array}{l}\text { 1)個人・世帯属性、居住状況 } \\
\text { 2)敷島公園の価值に関する評価 } \\
\text { (各項目について「とても思う」「やや思う」 } \\
\text { 「どちらでもない」「あまり思わない」 } \\
\text { 「まったく思わない」の5段階択一評価) } \\
\text { 3)公園の利用状況 } \\
\text { 4)QOLの評価 } \\
\text { (各項目について「満足」「やや満足」 } \\
\text { 「どちらでもない」「やや不満」「不満」 } \\
\text { の5段階択一評価) }\end{array}$ \\
\hline 回 収 数 & $\begin{array}{l}\text { 配布数: } 1800 \text { 票 } \\
\text { 回収数：472票，回収率： } 26.2 \% \\
\end{array}$ \\
\hline 調査主体 & $\begin{array}{l}\text { 前橋工科大学工学部社会環境工学科 } \\
\text { 地域 } \cdot \text { 交通計画研究室 }\end{array}$ \\
\hline
\end{tabular}

のキーワードを踏まえて都市公園を評価し分析した。

また，QOL は先行研究の結果 14)を参考にしながらも，本研究 では，敷島公園を取り巻く周辺地区の QOL の構成要素を再定義 して分析した。これにより，敷島公園の総合的価值が周辺住民の QOL に及ぼす影響をモデルとして仮定し, 総合的価值と QOL, 総合的価值と構成要素，QOL と構成要素との関係を定量的に明 らかにすることにより，都市公園の計画条件に有用となる基礎的 な知見を得ることを目的とした。

\section{2. 研究方法}

\section{(1) 対象及び構成}

敷島公園は，前橋市の中心市街地の北西部に位置する敷島町に あり，西側が利根川と接して園内に多数の松林がある。園内を含 む周辺は，敷島風致地区に指定された大規模公園である（種別： 運動公園, 面積: 約 36.6ha)。1922 年に国より河川敷と国有林が 前橋市に払い下げることによって公園として供用された（図－1）。

園内の北側には，陸上競技場，野球場やサッカー場，テニスコ 一トや水泳場など本格的なスポーツ需要に対応できる運動施設を 備えている。園内の西側には，開園当時の河川敷地を偲ばせる約 2,700 本の松林があるとともに, 600 種 7,000 株のバラが楽しめ るばら園がある。

\section{表-2 回答者の属性}

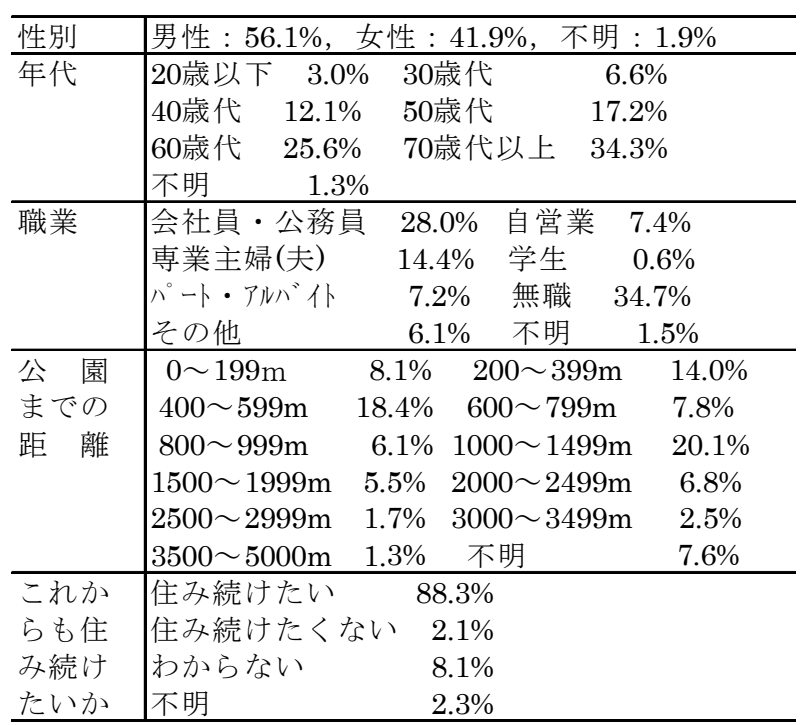

前橋市緑の基本計画を策定する際の市民アンケート調査におい ても，前橋市民が共有する緑のイメージの最上位に捉えられてお り，都市公園の価值が周辺地区の QOL に与える影響を判別でき ると考えたため研究対象とした。

本研究では，敷島公園の価值が QOL に及ぼす影響を把握する ため，敷島公園の周辺住民にアンケート調査を行った。調査の結 果は，敷島公園の価值に関する評価と合わせて，回答者の居住す る町の QOL の評価を把握した(3 章)。次に, アンケート調査で得 られた敷島公園の価值と QOL の評価結果に因子分析を適用する ことによって, 各々について代表的な因子を抽出して構成要素の まとまりに意味づけをした。以上の結果を踏まえ，敷島公園の価 值が QOL に与える影響を仮定したモデルに共分散構造分析を適 用して，その影響を定量的に把握した(4 章)。結果については，大 規模公園の価值が QOL に与える影響を把握した事例研究の 1 つ として, 敷島公園の価值と QOL の関係を踏まえて計画条件のあ り方について基礎的な考察を行った (5 章)。

\section{(2) アンケート調査}

2016 年 8 月 18 日, 敷島公園の所在地である敷島町, 緑ヶ丘町 を含み, 隣接する町である川原町, 荒牧町, 岩神町, 上小出町の 計 6 力町の住民を対象にアンケート調査を実施した（表一1）。 アンケート調査は，敷島公園の価值に関する評価と公園の利用状 況，QOL の評価について伺った。調査地区への配布は，地区内 の人口を考慮して配布数を設定した。調査用紙は, 調査員により 計 1800 部を個別配布し，後日に 472 部を郵送回収した(回収率: $26.2 \%$ )。表一2 は，回答者の属性を集計したものであり，60歳以 上の年代が全体の $59.9 \%$, 無職が $34.3 \%$, 敷島公園までの距離 $1000 \mathrm{~m}(1 \mathrm{~km})$ 未満が $54.4 \%$ 占めた。また，「これからも住多続け たいか」といら設問について 88.3\%が「住み続けたいりと答えた。

表-3 は，敷島公園の価值に関する評価項目である。評価項目 は，都市公園に関する既往研究 15)16)を参考に，敷島公園の実態を 踏まえて項目の加筆・削除を行い，「A1 : 生活に咊いや安らぎが 得られる」から，「A14：災害時の避難の場となる」の 14 個で構 成される項目と総合評価を加えた 15 項目とした。設問は, 各項 目ともに「どのように感じていますか」と伺い, 評価は,「とても 思う」から「まったく思わない」の 5 段階で評価してもらった。

表一 4 は，QOL を構成する評価項目である。設問は「あなたが 住んでいる地区の＜評価項目＞について，あなたはどのように感 じていますか」と伺った。評価項目は，QOL の評価に関する既 
表－3＼cjkstart公園の価値に関する評価項目

\begin{tabular}{|c|c|c|}
\hline 評価項目 & 略称 & 変数 \\
\hline 生活に䉋いや安らぎ & 䡚い・安らぎ & A1 \\
\hline 街にうるおいや開放感 & 潤い & $\mathrm{A} 2$ \\
\hline 地域の優れた景観 & 優れた景観 & $\mathrm{A} 3$ \\
\hline 身近に緑や自然を感じる & 緑・自然 & $\mathrm{A} 4$ \\
\hline 気分転換などによい & 気分転換 & A5 \\
\hline 散策や自然観察の場である & 散策 & A6 \\
\hline 地域の誇りである & 地域の誇り & A7 \\
\hline 地域の歴史や文化を表す & 歴史・文化 & A8 \\
\hline スポーツやレクをする場 & スポ・レク & A9 \\
\hline スポーツを観戦する場 & スポーツ観戦 & A10 \\
\hline お祭りやイベントの場 & お祭・イベント & A11 \\
\hline ウォーキリグやジョギングの場 & ウォーキング & A12 \\
\hline 子どもを遊ばせる場 & 遊び場 & A 13 \\
\hline 災害時の避難の場 & 避難場所 & A14 \\
\hline 総合評価 & 総合評価 & $\mathrm{AT}$ \\
\hline
\end{tabular}

\section{表-4ＱOL の評価項目}

\begin{tabular}{|c|c|c|}
\hline 評価項目 & 略称 & 変数 \\
\hline 買い物の便利さ & 買い物 & B1 \\
\hline 病院・福祉施設の便利さ & 病院・福祉 & $\mathrm{B} 2$ \\
\hline 郵便局や銀行の便利さ & 郵便・銀行 & B3 \\
\hline 通勤・通学の便利さ & 通勤 · 通学 & B4 \\
\hline 公共交通の便利さ & 公共交通 & B5 \\
\hline 歩きやすさ & 歩きやすさ & $\mathrm{B} 6$ \\
\hline まちなみや家なみのよさ & まちなみ & B7 \\
\hline 自転車の乗りやすさ & 自転車 & B8 \\
\hline 住宅、庭のゆとり & 住宅 & B9 \\
\hline 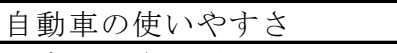 & 自動車 & B10 \\
\hline 日当たりや風通し & 日当たり & B11 \\
\hline 災害に関する安全性 & 災害安全性 & B12 \\
\hline 地区の防犯 & 防犯 & B13 \\
\hline 交通事故の危険が少ない & 交通安全 & B14 \\
\hline ゴミや排水などの衛生状況 & 衛生状況 & B15 \\
\hline 騒音・振動が少ない & 騒音・振動 & B16 \\
\hline 地域のまちづくり活動 & まちづくり & B17 \\
\hline 趣味やスポーツ活動 & 趣味・スポーツ & B18 \\
\hline 日頃の近所づきあい & 近所づきあい & B19 \\
\hline 総合評価 & 総合評価 & BT \\
\hline
\end{tabular}

往研究 14)を参考に，敷島公園の周辺の状況を踏まえ，敷島公園の 価值に関する評価と同様に項目の加筆・削除を行い，「B1：買い 物の便利さ」から，「B19：日頃の近所づきあい」の19個で構成 される項目と総合評価を加えた 20 項目とした。設問は, 各項目 とも「どのように感じていますか」と伺い, 評価は,「とても思う」 から「まったく思わない」の5段階で評価してもらった。

図-2 は，敷島公園の価值に関する評価の集計結果である。項 目を良好 (「とても思う」「やや思う」とした割合もの) と評価し た項目として，「A4:身近に緑や自然を感じられる(92.4\%)」「A1: 生活に数いや安らぎを得られる(84.7\%)」「A5:気分転換などによ い(84.7\%)」「A6:散策や自然観察の場である(82.7\%)」「A7:地域 の誇りである(81.7\%)」「A12:ウォーキングやジョギングの場で ある(81.6\%)」が挙げられた。

この結果から, 周辺住民にとって敷島公園は, A6 や A 12 の散 策やウォーキングといった利用機能に加えて， $\mathrm{A} 1 ， \mathrm{~A} 4 ， \mathrm{~A} 5, \mathrm{~A} 7$ といった緑のもたらす環境機能が良好と評価された。また，総合

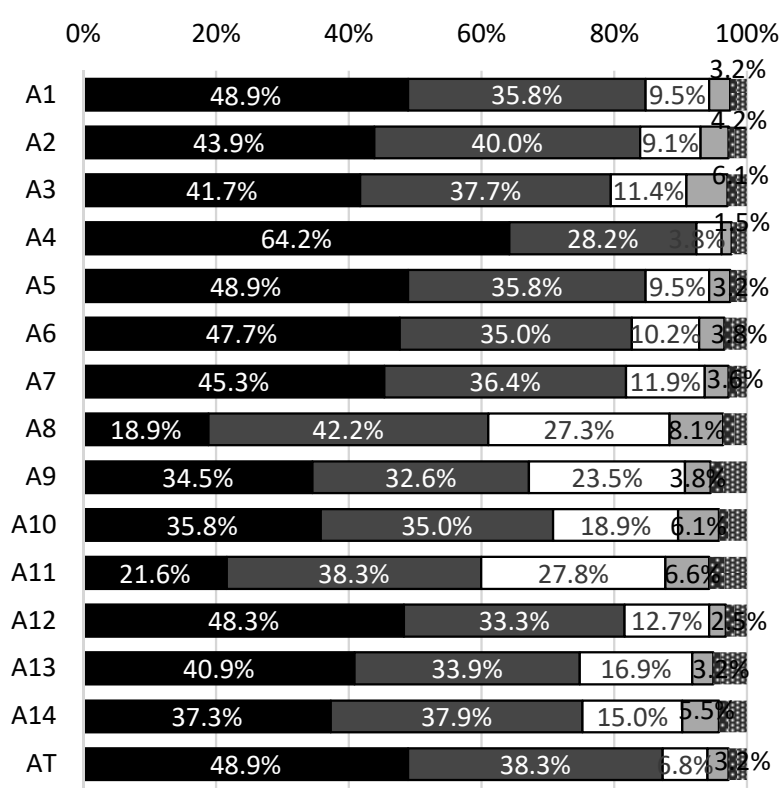

ロとても思う、ロや思う ロどちらでもない

ロあまり思わない ままったく思わない 瞰不明

図－2＼cjkstart公園の価値に関する評価

$\begin{array}{llllll}0 \% & 20 \% & 40 \% & 60 \% & 80 \% & 100 \%\end{array}$

\begin{tabular}{|c|c|c|c|}
\hline B1 & $35.2 \%$ & \begin{tabular}{|l|l|l}
$12.3 \%$ & $11.7 \%$ \\
\end{tabular} & $.40^{2}$ \\
\hline B2 & $35.8 \%$ & $28.2 \%$ & $9 \%$ \\
\hline B3 & $37.3 \%$ & $23.7 \%$ & 55 \\
\hline B4 & $26.7 \%$ & $112.3 \% 8$ & 8 \\
\hline B5 & $9 \% 20.3 \%$ & 23.5 & $5 \%$ \\
\hline & $43.2 \%$ & $19.9 \%$ & Q9.9\% \\
\hline B/ & $42.8 \%$ & $30.1 \%$ & 随. $1 \%$ \\
\hline B & $33.9 \%$ & $35.2 \%$ & $34 \%$ \\
\hline B9 & $44.1 \%$ & $24.2 \%$ & 䔩 $7 \%$ \\
\hline 10 & $39.2 \%$ & $28.8 \%$ & $0 \%$ \\
\hline B11 & $30.9 \%$ & 13. & 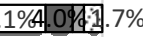 \\
\hline & $37.9 \%$ & $33.3 \%$ & 甠 $3 \%$ \\
\hline B13 & $36.0 \%$ & $39.4 \%$ & 雨 $9 \%$ \\
\hline B14 & $35.8 \%$ & $31.1 \%$ & 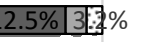 \\
\hline 315 & $27.3 \%$ & $17.2^{\circ}$ & 渑 $6 \%$ \\
\hline B16 & $30.3 \%$ & $15.0 \%$ & Alin $\%$ \\
\hline B17 & $33.7 \%$ & $48.1 \%$ & 可.1998 \\
\hline 18 & $30.9 \%$ & $49.8 \%$ & $255 \% 0 \%$ \\
\hline 319 & $34.5 \%$ & $44.1 \%$ & 相国 $3 \%$ \\
\hline B & 3 & & \\
\hline
\end{tabular}

$\begin{array}{lll}\text { ロ満足 } & \text { ロやや満足 } & \text { ロどちらでもない } \\ \text { ロやや不満 } & \text { ロ不満 } & \text { 曰不明 }\end{array}$

図一3 QOL の評価

的な評価項目である「AT:総合評価」については $87.2 \%$ 良好と 評価された。

図-3 は, QOL の評価の集計結果である。項目を良好（「満足」 「やや満足」とした割合が高いもの）と評価した項目として, 「B11:日当たりや風とおし(78.4\%)」「B15:ゴミや排水などの衛 生状況(73.5\%)」「B16:騒音や振動が少ない $(71.8 \%) 」 「 \mathrm{~B} 6$ :歩きや 寸さ(69.7\%)」が挙げられた。この結果から，周辺住民は，B11， 
表－5＼cjkstart因子分析（公園の価値に関する評価）

\begin{tabular}{|c|c|c|c|}
\hline 変数 & 略称 & 環境機能 & 利用機能 \\
\hline A1 & 憩い・安らぎ & 0.851 & 0.272 \\
\hline A2 & 潤い & 0.804 & 0.203 \\
\hline A3 & 優れた景観 & 0.784 & 0.195 \\
\hline A4 & 緑・自然 & 0.779 & 0.221 \\
\hline A5 & 気分転換 & 0.755 & 0.300 \\
\hline A6 & 散策 & 0.715 & 0.325 \\
\hline A7 & 地域の誇り & 0.714 & 0.231 \\
\hline A8 & 歴史 · 文化 & 0.583 & 0.240 \\
\hline A9 & スポ・レク & 0.223 & 0.854 \\
\hline A 10 & スポーツ観戦 & 0.142 & 0.807 \\
\hline A11 & お祭・イベント & 0.160 & 0.731 \\
\hline A 12 & ウォーキング & 0.432 & 0.619 \\
\hline A13 & 遊び場 & 0.410 & 0.538 \\
\hline A14 & 避難場所 & 0.272 & 0.451 \\
\hline 固有值 & & 5.05 & 3.30 \\
\hline 寄与率 & & $36.1 \%$ & $23.6 \%$ \\
\hline
\end{tabular}

表－6 因子分析（QOL の評価）

\begin{tabular}{|c|c|c|c|c|}
\hline 変数 & 生活利便 & $\begin{array}{l}\text { 住環境 } \\
\text { の良さ }\end{array}$ & 地域安全 & $\begin{array}{c}\text { 地域コミュ } \\
\text { ニティ }\end{array}$ \\
\hline B1 & 0.765 & 0.169 & 0.006 & 0.040 \\
\hline B2 & 0.740 & 0.072 & 0.161 & 0.131 \\
\hline B3 & 0.676 & 0.092 & 0.196 & 0.097 \\
\hline B4 & 0.674 & 0.151 & 0.016 & 0.054 \\
\hline B5 & 0.571 & 0.166 & 0.161 & 0.109 \\
\hline B6 & 0.214 & 0.701 & 0.249 & 0.146 \\
\hline B7 & 0.069 & 0.618 & 0.255 & 0.220 \\
\hline B8 & 0.275 & 0.593 & 0.198 & 0.105 \\
\hline B9 & 0.070 & 0.592 & 0.296 & 0.259 \\
\hline B10 & 0.357 & 0.569 & 0.172 & 0.093 \\
\hline B11 & 0.105 & 0.458 & 0.379 & 0.261 \\
\hline B12 & 0.227 & 0.199 & 0.671 & 0.184 \\
\hline B13 & 0.194 & 0.144 & 0.654 & 0.335 \\
\hline B14 & 0.086 & 0.279 & 0.647 & 0.158 \\
\hline B15 & 0.133 & 0.354 & 0.532 & 0.127 \\
\hline B16 & 0.030 & 0.311 & 0.495 & 0.062 \\
\hline B17 & 0.130 & 0.199 & 0.107 & 0.771 \\
\hline B18 & 0.099 & 0.238 & 0.191 & 0.651 \\
\hline B19 & 0.125 & 0.131 & 0.307 & 0.645 \\
\hline 固有值 & 2.80 & 2.67 & 2.49 & 1.89 \\
\hline \begin{tabular}{|c|} 
寄与率 \\
\end{tabular} & $14.7 \%$ & $14.1 \%$ & $13.1 \%$ & $10.0 \%$ \\
\hline
\end{tabular}

$\mathrm{B} 15$ 及び B 16 といった日当たりや衛生状況, 騒音・振動といった 項目が良好と評価された。また，地区内の総合的な評価である 「BT: 総合評価」については 83.7\%が良好と評価された。

\section{3. 分析結果}

\section{（1）因子分析}

表一 5 は, 敷島公園の価值に関する評価特性を探るため, 表一 3 に示した A1 から A14 までの項目の評価結果について因子分析を 適用した結果である（抽出された因子が互いに個性を持つようバ リマックス回転変換を適用)。分析結果から探査的に因子負荷量 0.45 以上の值を基淮に 2 つ代表する因子を抽出した。第 1 因子 は，「A1租い・安らぎ(0.851)」「A2:潤い(0.804)」「A3:優れた景観 (0.784)」「A4:緑・自然(0.779)」など緑による心理的効果に関する 項目，「A6:散策(0.715)」「A7:地域の誇り(0.583)」など緑による付 加価值に関する項目など, 緑の存在すなわち環境に関する因子負 荷量の值が大きいことから，「環境機能(寄与率:36.1\%)」と意味づ けた。同様に，第 2 因子は，「A9:スポ・レク(0.854)」「A10:スポ 一ツ観戦(0.807)」「A11:お祭り・イベント(0.731)」などオープン
表－7 2群の母平均の検定（公園の価値に関する評価）

\begin{tabular}{|c|c|c|c|c|}
\hline 性別 & 男性 & 女性 & $\mathrm{P}$ 值 & 検定 \\
\hline 環境機能 & -0.024 & 0.034 & 0.522 & - \\
\hline 利用機能 & -0.011 & 0.017 & 0.749 & - \\
\hline 年齢 & 59歳以下 & 60歳以上 & P值 & 検定 \\
\hline 環境機能 & -0.118 & 0.074 & 0.035 & * \\
\hline 利用機能 & -0.027 & 0.025 & 0.556 & \\
\hline 距離 & $1 \mathrm{~km}$ 末満 & $1 \mathrm{~km}$ 以上 & P值 & 検定 \\
\hline 環境機能 & 0.126 & -0.151 & 0.002 & $* *$ \\
\hline 利用機能 & -0.011 & 0.013 & 0.781 & \\
\hline 定住意識 & 住み続けたい & $\begin{array}{c}\text { 住み続けたくない } \\
\text { わからない }\end{array}$ & P值 & 検定 \\
\hline 環境機能 & 0.042 & -0.406 & 0.002 & $* *$ \\
\hline 利用機能 & 0.021 & -0.090 & 0.437 & - \\
\hline
\end{tabular}

表－8２群の母平均の検定（QOL の評価）

\begin{tabular}{|c|c|c|c|c|}
\hline 性別 & 男性 & 女性 & $\mathrm{P}$ 值 & 検定 \\
\hline 生活利便 & 0.041 & -0.064 & 0.224 & - \\
\hline 住環境の良さ & 0.003 & -0.005 & 0.918 & - \\
\hline 地域安全 & 0.079 & -0.092 & 0.034 & $*$ \\
\hline 地域コミュニティ & 0.014 & -0.037 & 0.528 & - \\
\hline 年齢 & 59歳以下 & 60歳以上 & $\mathrm{P}$ 值 & 検定 \\
\hline 生活利便 & 0.044 & -0.040 & 0.336 & - \\
\hline 住環境の良さ & -0.033 & 0.024 & 0.489 & - \\
\hline 地域安全 & -0.273 & 0.191 & 0.000 & $* *$ \\
\hline 地域コミュニティ & -0.140 & 0.087 & 0.005 & *** \\
\hline 距離 & $1 \mathrm{~km}$ 未満 & $1 \mathrm{~km}$ 以上 & $\mathrm{P}$ 值 & 検定 \\
\hline 生活利便 & -0.159 & 0.262 & 0.000 & $* *$ \\
\hline 住環境の良さ & 0.066 & -0.100 & 0.051 & - \\
\hline 地域安全 & 0.036 & -0.058 & 0.246 & - \\
\hline 地域コミュニティ & -0.009 & 0.025 & 0.695 & - \\
\hline 定住意識 & 住み続けたい & $\begin{array}{c}\text { 住み続けたくない } \\
\text { わからない }\end{array}$ & $\mathrm{P}$ 值 & 検定 \\
\hline 生活利便 & 0.021 & -0.250 & 0.053 & - \\
\hline 住環境の良さ & 0.014 & -0.062 & 0.567 & - \\
\hline 地域安全 & 0.041 & -0.395 & 0.001 & $* *$ \\
\hline 地域コミュニティ & 0.015 & -0.144 & 0.223 & - \\
\hline
\end{tabular}

スペースを利用することに関する項目などの因子負荷量の值が大 きいことから「利用機能（寄与率 $23.6 \%$ )」と意味づけた。

表一6 は，調査を行った地区における QOL 評価の特性を具体 的に探るため, 因子分析を適用したものである。分析結果から探 查的に因子負荷量 0.45 以上の值を基準として, 4 つの代表する因 子を抽出した。第 1 因子は, 「B1:買い物(0.765)」「B2:病院・福祉 (0.740)」「B3: 郵便・銀行(0.676)」「B4:通勤・通学(0.674)」など, 生活利便に関する項目の因子負荷量の值が大きいことから，「生 活利便(寄与率: 14.7\%)」と意味づけた。同様に, 第 2 因子は, 「B6: 歩きやすさ(0.701)」「B7:まちなみ(0.618)」「B8:自転車(0.593)」 など，住環境を構成する要素に関する項目の因子負荷量の值が大 きいことから「住環境の良さ（寄与率 : $14.1 \%$ ）と意味づけた。

さらに，第 3 因子は，「B12:災害安全性(0.671)」「B13:防犯 (0.654)」「B14: 交通安全(0.647)」など，地域の安全に関する項目 の因子負荷量の值が大きいことから「地域安全 (寄与率: 13.1\%)」 と意味づけた。第 4 因子は, 「B17:まちづくり(0.771)」「B18:趣 味・スポーツ(0.651)」「B19:近所づきあい(0.645)」など, 地域の 空間や交流に関する項目の因子負荷量の值が大きいことから「地 域コミュニティ（寄与率 : $10.0 \%$ ）と意味づけた。

\section{（2）属性にみる評価特性}

表一7 はA1 から A14 までの敷島公園の価值に関する評価，表 -8は B1 から B19 までの地区の QOL の評価について，性別， 年齢, 敷島公園までの距離, 定住意識の 4 つの属性別特性を把握 するため, 先に因子分析で得られた因子得点の因子別の平均值を 用い， 2 群の母平均の検定を行ったものである。

年齢については, 60 歳以上が約 6 割を占めること, 還暦を迎え 


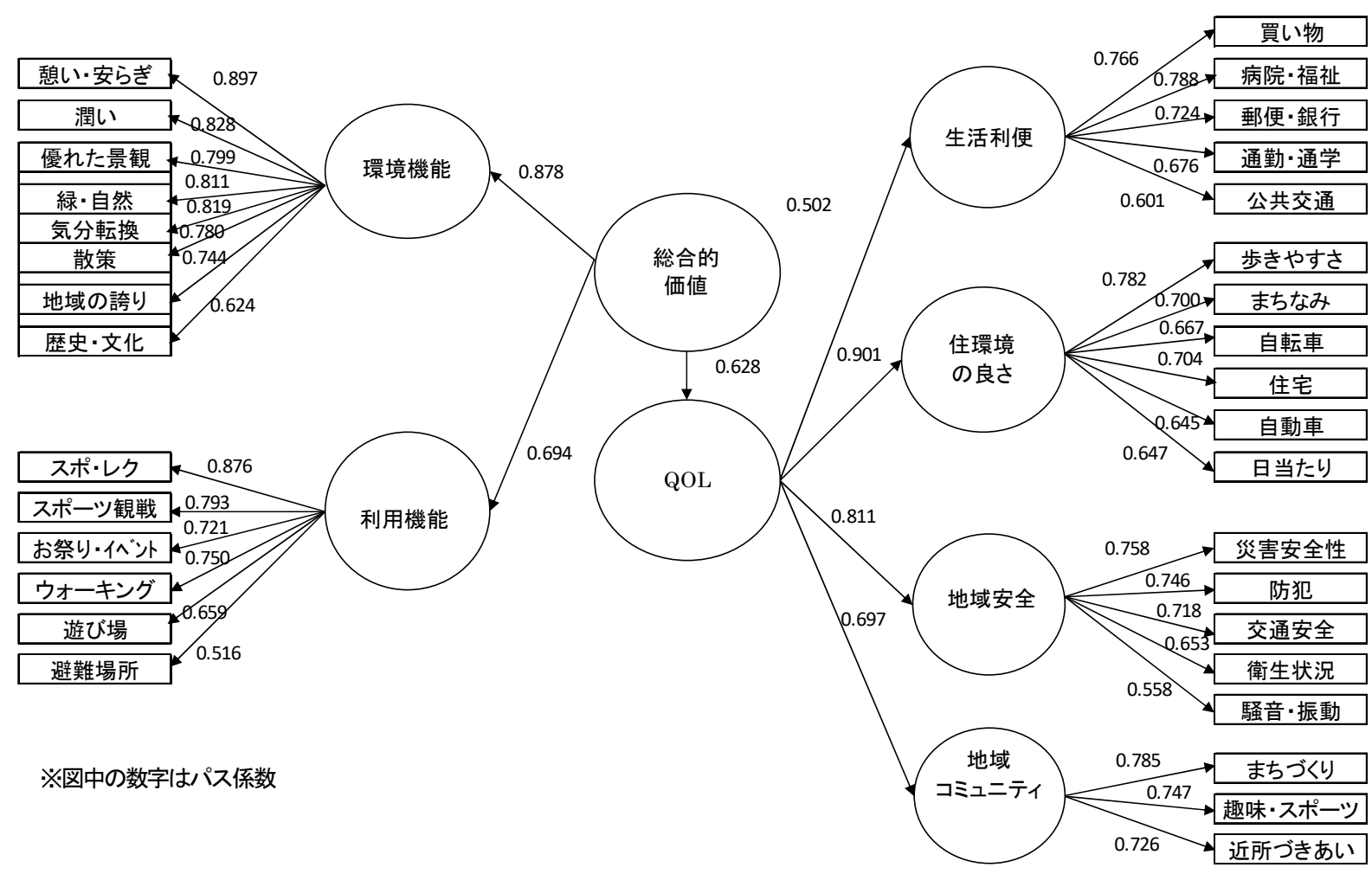

図－4敷島公園を事例とした総合的価值と Q0L の評価モデル

ることにより所得や就業形態などライフスタイルが変化する 17) ことから, 都市公園の利活用や緑の嗜好や認知に年代として大き な差異があると考えて「59歳以下」と「60歳以上」に分類した。

また，敷島公園のような大規模公園の利用圈域は $1 \mathrm{~km}$ 以上も 考えられるが，近隣住区としての基礎単位である歩行圈域を考慮 して「 $1 \mathrm{~km}$ 未満」と「 $1 \mathrm{~km}$ 以上」に分類した。さらに，定住意 識は「住タ続けたい」と「住み続けたくない・わからないりに分 類し，それぞれ 2 群の母平均の差の検定を行った。

分析の結果，敷島公園の価值に関する評価では，利用機能の全 てに差異が認められなかったものの，環境機能においては，年齢 で「59 歳以下」よりも「60 歳以上」が高い值に評価する傾向が 把握された ( $5 \%$ 有意水準)。また, 距離では「 $1 \mathrm{~km}$ 未満」が「 $1 \mathrm{~km}$ 以上」よりも, 定住意識では,「住み続けたい」よりも「住み続け たくない・わからないが高い值に評価する傾向が把握された ( $1 \%$ 有意水淮)。

地区の QOL の評価では，地域安全においては，性別で「男性」 よりも「女性」(5\%有意水淮)，「60歳以上」よりも「59歳以下」 (1\%有意水準)，「住み続けたい」が「住み続けたくない・わから ない」(1\%有意水準)よりも高い值に評価する傾向が把握された。

また，地域コミュニティにおいては，「60歳以上」よりも「59 歳以下」が高い值に評価する傾向が把握された ( $1 \%$ 有意水淮)。 さらに, 生活利便においては, 「1 $\mathrm{km}$ 以上」よりも「 $1 \mathrm{~km}$ 未満」 が高い值に評価する傾向が把握された（1\%有意水準）。

\section{4. 敷島公園の利用のための環境と QOL の評価モデル}

\section{(1) 評価モデル}

敷島公園の総合的価值と環境機能及ひ利用機能，環境機能と利 用機能の各々が構成する要素との関係, QOL と 4 つの因子 (生 活利便, 住環境の良さ, 地域安全, 地域コミュニティ）との関係, 4 つの因子と各々が構成する要素との関係を定量的に把握するた めのモデルを仮定して共分散構造分析を行った。モデルは，図一

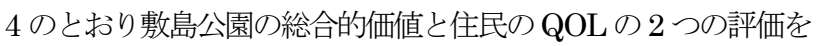

統合した評価モデルとした。モデルは潜在変数として設定した「公 園の価值に関する評価」と「QOL の評価」間には，回帰分析的 な因果関係を仮定した典型的な多重指標モデルを設定した 18)。

また，敷島公園の「総合的価值」の下位には，因子分析によっ て抽出された，環境機能」と「利用機能」の 2 つの因子を潜在 変数として配置し, 配置した因子の下位に A1 から A14 の評価を 観測変数として配置した 3 階層から成る因子分析モデルとした。 敷島公園の価值と同様に「QOL」の下位には，因子分析によっ て抽出された「生活利便」「住環境の良さ」「地域安全」「地域コミ ユニティ」の 4 つ因子を潜在変数として配置し, 配置した因子 の下位に B1 から B19 の評価を観則変数として設定した 3 階層か ら成る因子分析モデルとした。

\section{(2) 分析結果}

モデル全体の適合度指標は, GFI 及び AGFI の值が 0.9 以上,

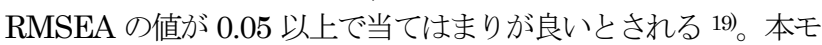
デルでは, GFI が 0.832, AGFI が 0.807, RMSEA が 0.066 で あり当てはまりの良い值に近い值が得られた。潜在変数と潜在変 数, 潜在変数と観測変数の間のパス係数は全て $1 \%$ の有意水準を 満たした。「総合的価値」と「環境機能」及び「利用機能」の関係 に着目寸ると,「総合的価値が最も大きい影響を与える潜在変数 は「環境機能(0.873)」であった。潜在变数と観測变数の関係に着 目寸ると，「環境機能」に大きな影響を与える観測変数は，「䊝 い・安らぎ(0.897)」「うるおい(0.828)」「気分転換(0.819)」「緑や 自然(0.811)」であった。「利用機能」に大きな影響を与える勧測

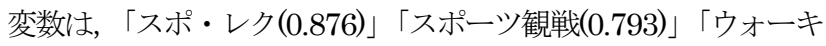
ング(0.750)」であった。

次に「QOL」と因子分析で抽出した 4 つの潜在変数に着目す ると「QOL」が最も大きな影響を与えた潜在変数は，「住環境の

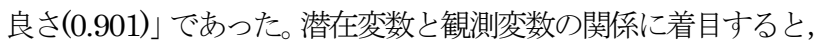
各潜在変数に大きな影響を与える観測変数として, 「生活利便が 「病院・福祉(0.788)」，「住環境の良さ」が「歩きやすさ(0.782)」 「地域安全」が「災害安全性(0.758)」「地域コミュニティ」が「ま 
ちづくり(0.785)」にそれぞれ強い影響を与えた。「総合的価值」 が「QOL」に与える影響のパス係数は 0.628 であった。

\section{5. まとめ}

\section{(1) 分析のまとめ}

敷島公園の「総合的価值」が「QOL」に影響を与えるという仮 定に基づき敷島公園の価值と QOL に関するアンケート調査を行 いモデル化して共分散構造分析を行った。結果，敷島公園の「総 合的価值」を構成する要素, 「総合的価值」と「QOL」,「QOL」 を構成する要素の 3 つの関係を定量的に把握することができた。 アンケート調査の結果では，敷島公園の「総合的価值」に「環 境機能」と「利用機能」，「QOL」に「生活利便」「住環境の良さ」 「地域安全」「地域コミュニティ」の代表する因子を抽出した。

因子得点を用いて, 性別, 年齢, 距離, 定住意識の属性別の分 析を行った結果, 性別においては大きな差異が見られなかったが,

$\lceil 60$ 歳以上」と「59 歳未満」,「 $1 \mathrm{~km}$ 以上」と「 $1 \mathrm{~km}$ 未満」,「住 み続けたい」と「住み続けたくない・わからない」の 2 群につい て，公園の価值に関する評価と QOL の評価を構成する一部の結 果に差異が認められた。

さらに，敷島公園の「総合的価值」と「QOL」との関係をより 具体的に探るためにモデルを仮定し共分散構造分析を行った。結 果，「総合的価值」と「環境機能」及び「利用機能」の関係，「総 合的価值」と「QOL」の関係を定量的に明らかにした。敷島公園 の「総合的価值」は，「利用機能」と比較して「環境機能」の方に 大きな影響を与えること，「総合的価值」が「QOL」に大きな影 響を与えること，「QOL」が「住環境の良さ」に与える影響が他 の構成要素と比較し大きな影響を与えることを把握した。すなわ ち, 敷島公園の「総合的価值」は，周辺住民の「QOL」に影響を 与えているという仮説を調査結果から定量的に導くことができた と考える。

\section{（2）考察及び今後の課題}

敷島公園の「総合的価值」が「QOL」に与える影響は，「総合 的価值」が「利用機能」に与える影響と同程度の大きさの影響を 与えていることが分かった。また，「QOL」が 4 つの構成因子の 中で，最も大きい影響を与えたのは「住環境の良さ」であること が分かった。環境機能」においては，年齢で「59 歳以下」より も「60歳以上」が高い值で評価する傾向が把握された。また, 「地 域安全」や「地域コミュニティ」においては，「59 歳以下」より も「60歳以上」が高い值で評価する傾向が把握された。

この結果からも CCRC 構想を展開する中で, 高齢者が生きがい を持ち健康を維持する環境づくりとして，敷島公園の「憩い・安 らぎ」の「環境機能」を高めるように，「憩い・安らぎ」を提供で きる高質空間の提供, 防災施設やコミュニティ施設などの導入が, 敷島公園の「総合的価值」を高めるために効果的であると考えた。 また，これは，敷島公園周辺地区における「QOL の評価」の「住 環境の良さ」や「地域コミュニテイ」の双方を高める意味でも効 果的であると考えた。さらに，敷島公園を事例とした検討結果か ら，立地適正化計画による居住誘導区域を設定する場合には，都 市公園の「総合的価值」と「QOL の評価」を考慮して施設内容 を検討していくことも有効であると考えた。

人口減少・少子高齢化などの社会情勢の変化を背景として，都 市政策全体が転換点を迎えている中，居住や都市の生活を支える 機能の誘導によるコンパクトなまちづくりと地域交通の再編との 連携による都市構造が模索されている。一方で，都市公園をはじ めとする緑とオープンスペースは，これからの将来の都市及び住 民に対し，如何なる役割を果たすべきか，多様化するニーズにど う応えるべきかなどの課題に面しているといえる。

今回の事例研究では, QOL の重要な構成要素である「住環境
の良さ」を高めるために，敷島公園の総合的価值が大きな影響を 与えていたことを定量的に把握寸ることができた。今後の課題と しては，敷島公園以外の大規模公園を評価することによって，都 市公園の総合的価值に関する評価を高める計画的手法を具体的に 示していくこと，また身近にある小公園と今回対象とした大規模 公園との総合的価值に関する評価の相違性などについて，引き続 き比較検討を行っていくことが考えられる。

\section{補注及び引用文献}

1)首相官邸ホームページ：日本版 CCRC 構想有識者会議（素案）, http://www.kantei.go.jp/jp/singi/sousei/meeting/ccrc/ccrc_soan.pdf (2017.11.25 閲覽)

2)国土交通省 : 重要的施策（コンパクトシティ・プラス・ネットワーク）, http://www.mlit.go.jp/toshi/toshi_ccpn_000016.html (2017.11.25 閲覧) 3)国土交通省 : 公園とみどり,

http://www.mlit.go.jp/common/001188913.pdf（2017.8.20閲覧）

4)中西仁美・土井健司（2003）QOL に関する概念整理一政策評価やベン チマークシステムとの関連性からー, 土木計画学研究・講演集 No27,

CD-ROM.

5)林良嗣, 土井健司, 杉山郁夫 (2004) 生活質の定量化に基づく社会資本 整備の評価に関する研究，土木学会論文集 No.751 (IV-62)，pp.55-70 6)田中美穂・包清博之・杉本正美(2001) : 市街地の状況の違いと公園利用 行動からみた公園に対する評価特性に関する基礎的研究，造園雑誌 No.64, pp.655-658

7)蔡鴻昌・武田重昭・加我宏之・増田昇(2014) : アクセシビリティから捉 えた都市公園の選択性の評価に関する研究大阪府堺市を事例として: 都 市計画論文集 Vol. 49(3)， pp. 261-266

8)上原奏・佐藤宏亮(2016) : 親水公園の歩行空間の連続性に着目した高齢 者の移動経路に関する研究-江東区の親水公園を対象として: 都市計画論 文集 Vol. 51(3)， pp. 299-304

9)田中稲子・ 三輪律江・松橋圭子・谷口新(2009) : 横浜市における駅前保 育施設の園外活動の場としての街区公園利用とその評価に関寸る研究, 都市計画論文集 Vol. 44(3)，pp. 373-378

10)椎野西紀夫(2017): 保育施設利用から見た面積狭小小都市公園の再評価 の手法に関する検討 : ランドスケープ研究 80(5), pp.489-492

11)小林昭裕(2017) : 東京郊外に立地する都市公園を事例とした文化的生態 系サービスに関する評価手法の検討 : ランドスケープ研究 80(5), pp. $521-526$

12)(社)日本公園緑地協会(2010) : 公園緑地マニュアル, pp.13-14

13)群馬県立敷島公園 HP:前橋市管理エリアマップ,

http://shikishima-park.org/pdf/city_map.pdf

14) Tetsuo MORITA, Yoshihito KOGURE, Hiroshi SUGITA, Tsuyoshi BABA, Shinya TSUKADA and Naoki MIYAZATO(2012): A Study on Evaluation of Quality of Life in Consideration of Water/Green Environment, International Journal of GEOMATE, Vol.2(2), pp. $241-246$

15)塚田伸也・湯沢昭（2004）: 大公園における利用者の評価構造に関する 検討一前橋市の総合公園を事例として, 都市計画論文集 Vol.39(3), pp. $193-198$

16)塚田伸也・岩間佳之・湯沢昭(2005), 前橋市の総合公園(前橋公園)を事 例とした地方都市における市街地大公園の利用的課題, ランドスケープ 研究 69(5), pp. 597-600

17)内閣府 : 平成 29 年版高齢社会白書 (全体版), http://www8.cao.go.jp/kourei/whitepaper/w-2017/html/zenbun/index. $\mathrm{html}(2018.1 .28$ 閲覧)

18)涌井良幸・涌井貞美(2003) : 図解でわかる共分散構造分析 : (株)日本実 業出版社，pp.140-145

19)豊田秀樹(1998) : 共分散構造分析 : 朝倉書店, pp.170-177 